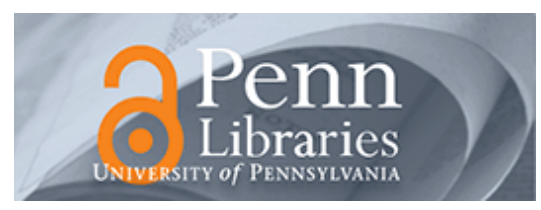

Manuscript Studies

\title{
Multispectral Recovery of a Fragment of Richard FitzRalph's Summa de Questionibus Armenorum from University of Rochester, D.460 1000-03
}

Kyle Ann Huskin

University of Rochester, kyle.huskin@gmail.com

Alexander J. Zawacki

University of Rochester, alexander.zawacki@gmail.com

Gregory Heyworth

University of Rochester, gregory.heyworth@rochester.edu

Follow this and additional works at: https://repository.upenn.edu/mss_sims

Part of the Digital Humanities Commons, and the Medieval Studies Commons

\section{Recommended Citation}

Huskin, Kyle Ann; Zawacki, Alexander J.; and Heyworth, Gregory (2019) "Multispectral Recovery of a Fragment of Richard FitzRalph's Summa de Questionibus Armenorum from University of Rochester, D.460 1000-03," Manuscript Studies: Vol. 4 : Iss. 2 , Article 5.

Available at: https://repository.upenn.edu/mss_sims/vol4/iss2/5 


\title{
Multispectral Recovery of a Fragment of Richard FitzRalph's Summa de Questionibus Armenorum from University of Rochester, D.460 1000-03
}

\begin{abstract}
Multispectral imaging -the process of obtaining image data from a range of both visible and invisible wavelengths-is a new frontier in medieval studies, raising the possibility of recovering damaged or palimpsested texts that have been illegible for centuries. In this paper we show the remarkable results of applying this technology to University of X, MS D.460 1000-003, a previously unidentified single-folio fragment that was gifted to the university in 1968. Formerly used as a limp vellum binding for a seventeenth-century volume, the text has become so worn that it is all but completely unreadable to the naked eye. The fragment has consequently received little scholarly attention prior to our investigation. Our team recovered nearly all of the lost text and identified the fragment as an excerpt from Richard FitzRalph's Summa de Questionibus Armenorum. Although this text survives in 45 other manuscripts and fragments, our discovery is highly significant because the Rochester fragment is the only copy of any of FitzRalph's works in a non-European collection. Moreover, the fragment, whose handwriting dates to no later than 1370, may be the oldest extant copy of the Summa by at least half a decade. We present the process of this discovery, our conclusions about the text, and the potential for multispectral imaging to unlock new information hidden in known but understudied fragments held in archival collections around the world.
\end{abstract}

\section{Keywords}

Manuscript studies, multispectral, richard fitzralph, fragment, 14th century, manuscript, medieval 


\title{
MANUSCRIPT STUDIES
}

A Journal of the Schoenberg Institute for Manuscript Studies

\author{
VOLUME 4, NUMBER 2
}

(Fall 2019)

Manuscript Studies (ISSN 2381-5329) is published semiannually
by the University of Pennsylvania Press

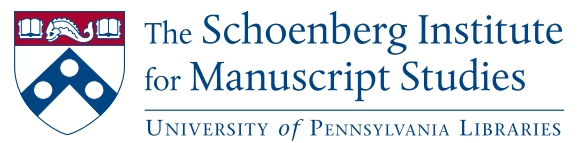




\section{MANUSCRIPT STUDIES}

VOLUME 4, N U M B E 2

(Fall 2019)

ISSN 2381-5329

Copyright (C 2019 University of Pennsylvania Libraries

and University of Pennsylvania Press. All rights reserved.

Published by the University of Pennsylvania Press, 3905 Spruce Street, Philadelphia, PA 19104.

Printed in the U.S.A. on acid-free paper.

Manuscript Studies brings together scholarship from around the world and across disciplines related to the study of premodern manuscript books and documents, with a special emphasis on the role of digital technologies in advancing manuscript research. Articles for submission should be prepared according to the Chicago Manual of Style, $16^{\text {th }}$ edition, and follow the style guidelines found at http://mss.pennpress.org.

None of the contents of this journal may be reproduced without prior written consent of the University of Pennsylvania Press. Authorization to photocopy is granted by the University of Pennsylvania Press for libraries or other users registered with Copyright Clearance Center (CCC) Transaction Reporting Service, provided that all required fees are verified with CCC and paid directly to CCC, 222 Rosewood Drive, Danvers, MA 01923. This consent does not extend to other kinds of copying for general distribution, for advertising or promotional purposes, for creating new collective works, for database retrieval, or for resale.

\section{SUBSCRIPTION INFORMATION:}

Single issues: $\$ 30$

Print and online subscriptions: Individuals: $\$ 40$; Institutions: $\$ 92$; Full-time Students: $\$ 30$ International subscribers, please add $\$ 19$ per year for shipping.

Online-only subscriptions: Individuals: $\$ 32$; Institutions: $\$ 80$

Please direct all subscription orders, inquiries, requests for single issues, address changes, and other business communications to Penn Press Journals, 3905 Spruce Street, Philadelphia, PA 19104. Phone: 215-573-1295. Fax: 215-746-3636. Email: journals@pobox.upenn.edu. Prepayment is required. Orders may be charged to MasterCard, Visa, and American Express credit cards. Checks and money orders should be made payable to "University of Pennsylvania Press" and sent to the address printed directly above.

One-year subscriptions are valid January 1 through December 31. Subscriptions received after October 31 in any year become effective the following January 1. Subscribers joining midyear receive immediately copies of all issues of Manuscript Studies already in print for that year.

Postmaster: send address changes to Penn Press Journals, 3905 Spruce Street, Philadelphia, PA 19104.

Visit Manuscript Studies on the web at mss.pennpress.org. 


\section{MANUSCRIPT STUDIES}

\section{A Journal of the Schoenberg Institute for Manuscript Studies}

V OL U M E 4, N U M B E R 2

\section{Articles}

Moralizing the Mass in the Butler Hours

KATHRYN A. Smith

Clockwise-Counterclockwise: Calligraphic Frames in Sephardic Hebrew Bibles and Their Roots in Mediterranean Culture

Dalia-Ruth Halperin

Breaking and Remaking Scripture: The Life, Death, and Afterlife of the Hornby-Cockerell Bible

ERIC J. JOHNSON

Visualizing Codicologically and Textually

Complex Manuscripts

Anna Dorofeeva

Multispectral Recovery of a Fragment of Richard FitzRalph's

Summa de Questionibus Armenorum from University of

Rochester, D.460 1000-03

Kyle Ann Huskin, Alexander J. Zawacki, Gregory Heyworth

\section{Annotations}

Two Unusual Mind Diagrams in a Late Fifteenth-Century

Manuscript (UPenn Schoenberg Collection, LJS 429)

Mary J. Carruthers

Labecule Vivex: Building a Reference Library of Stains

for Medieval and Early Modern Manuscripts

Alberto Campagnolo, Erin Connelly, Heather Wacha 
Manuscript Studies, Vol. 4 [2019], Iss. 2, Art. 5

iv | Journal for Manuscript Studies

\section{Reviews}

Mauro Nobili and Andrea Brigaglia, eds.

The Arts and Crafts of Literacy: Islamic Manuscript

Cultures in Sub-Saharan Africa.

Evyn KropF

Catherine A. Bradley and Karen Desmond, eds. The

Montpellier Codex: The Final Fascicle. Contents, Contexts,

Chronologies.

Flannery Cunningham

Laura Cleaver and Andrea Worm, eds. Writing History in the Anglo-Norman World: Manuscripts, Makers, and Readers, $c$. 1066-c. 1250.

JaCQueline M. Burek

Mariken Teeuwen and Irene van Renswoude, eds.

The Annotated Book in the Early Middle Ages:

Practices of Reading and Writing.

Christine E. BACHMAN 


\title{
Multispectral Recovery of a Fragment of Richard FitzRalph's Summa de Questionibus Armenorum from University of Rochester, D.460 1000-03
}

\author{
Kyle Ann Huskin \\ University of Rochester \\ Alex ANDER J. ZAWACKI \\ University of Rochester \\ GREgORY HeYWORTH \\ University of Rochester
}

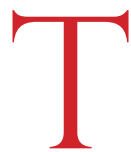

he Lazarus Project is an interdisciplinary initiative at the University of Rochester that uses multispectral imaging (MSI) - the invisible wavelengths - to recover damaged or illegible texts and cultural heritage objects. Here, we apply this technology to the "Ricardus Dialogue" (University of Rochester, D.460 1000-003). ${ }^{1}$ A single-folio fragment gifted to the university by Winifred Myers in 1968, the Ricardus Dialogue's earlier provenance was virtually unknown. To the naked eye, the text is almost completely illegible beyond the rubricated names Ricardus and Iobannes (fig. 1), a

1 The manuscript fragment acquired this informal name within the University of Rochester because, as noted, only the names Ricardus and Iohannes could be read, and because these personae are clearly engaged in dialogue. We will retain this name throughout. 
shortcoming that has, until now, hampered its study. However, using MSI technology and statistical image processing, our team successfully recovered the vast majority of the text and identified the document as an early witness to Richard FitzRalph's Summa de Questionibus Armenorum (ca. 1348-51). A dialogic exposition in nineteen books of the official Roman Catholic doctrine for Armenian prelates, the Summa has been described as "FitzRalph's most important and influential contribution to medieval theological literature." Our discovery is significant because not only does our fragment appear to be one of the earliest extant copies of the text, but it is also the first manuscript of any of FitzRalph's works to be identified in a nonEuropean collection. Inasmuch as the Summa has not benefited from a scholarly edition since $1511 / 12$, we have chosen to present a full transcription of the recovered text in anticipation of a future collation of the work and its variants.

\section{Physical Description}

The Ricardus Dialogue is a single folio that measures $25 \times 16.5 \mathrm{~cm}$. Originally larger, it was excised from its original codex sometime before 1675 and refashioned into a limp vellum cover. During the excision, approximately $1.9 \mathrm{~cm}$ appears to have been trimmed vertically from the from the left margin of the recto, resulting in the loss of text from recto, column a, and verso, column b. It may be surmised from the lack of a header designating the book number that some amount of parchment (probably slightly less than $3 \mathrm{~cm}$ ) was trimmed from the top of the folio; some form of numbering system for the various libri is present in nearly all other witnesses that we consulted. ${ }^{3}$ The fragment's original measurements, therefore, were likely about $28 \times 18.4 \mathrm{~cm}$.

2 Katherine Walsh, A Fourteenth-Century Scholar and Primate: Richard FitzRalph in Oxford, Avignon, and Armagh (Oxford: Clarendon Press, 1981), 126.

3 The other witnesses to which we compared our fragment are Vatican City, Biblioteca Apostolica Vaticana, MSS Vat. lat. 1033, 1034, 1035, and 1036; only MS 1036 lacks consistent headers. 
Huskin et al.: Multispectral Recovery of Summa de Questionibus Armenorum

Huskin, Zawacki, and Heyworth, Multispectral Recovery of a Fragment | 363

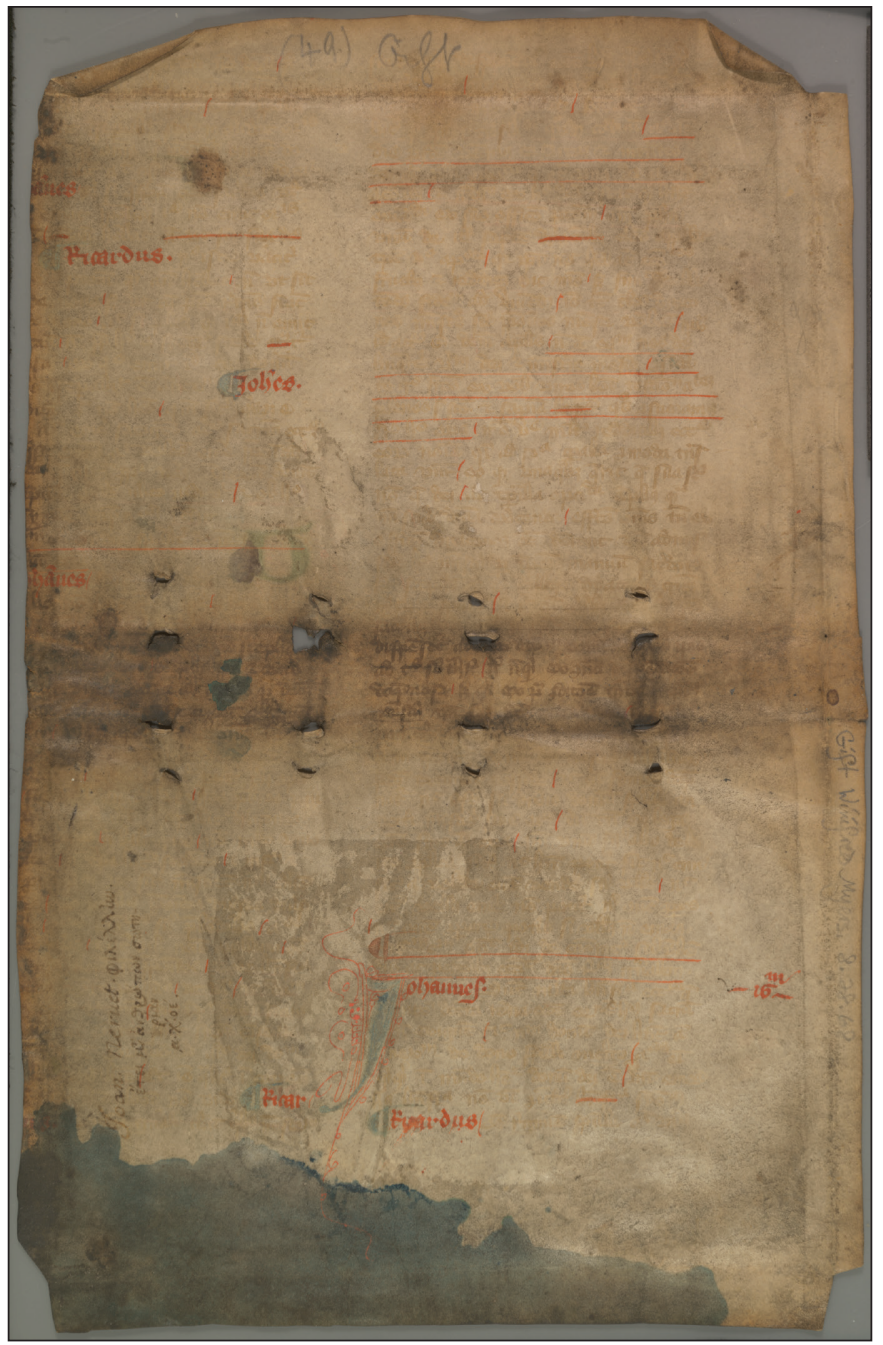

FIGURE 1. The verso side of the folio as it appears to the naked eye.

After resizing, the folio was rotated 90 degrees clockwise and made into a cover for an unidentified volume. The center of the folio was incorporated into the spine of this book: eight holes run across the page, the vestiges of four evenly-spaced sewing supports whose lacing followed a straight lacing path, appear to have extended about $3.3 \mathrm{~cm}$ inward from the edge of the 
text block. Tannins and oils from the leather book cover have discolored about $1.9 \mathrm{~cm}$ (spreading to about $5 \mathrm{~cm}$ at its greatest extent) of the central portion of the folio (hereafter referred to as the "spine"). This discoloration has rendered six lines in both verso columns completely illegible. Fortunately, however, the discoloration had the opposite effect in some portions of the recto spine area, where the text faced inward toward the sewing supports.

Creases, paste residue, and beveling are visible along all four edges, indicating where the parchment was turned in about $0.5 \mathrm{~cm}$ along the vertical sides and $0.9 \mathrm{~cm}$ along the horizontal. Paste residue, almost certainly from a bookplate, is visible on the lower portion of the recto, on what would have been the inside front cover of the rebound book. Early modern handwriting appears in three locations - twice on the verso and once on the recto. The inscription on the recto, located just above the residue left by the bookplate, remains clearly legible, and reads Joan Neruet. $\sigma \omega \tau \eta \mid$ giav $\mid \alpha \cdot \chi \cdot \Delta \dot{\varepsilon}^{4}{ }^{4}$ On the verso, four lines of writing are visible in the far-left portion of the spine. Though severe staining impeded efforts to recover this inscription to the point of legibility, it likely gives the title of the text around which the folio was bound, as it is located in the upper spine region and would have faced outward when shelved. It appears to be written in a hand contemporary with Jean Nervet's inscription (1675), if not by Nervet himself.

The bottom of the fragment is discolored by a large blue stain, probably from a copper-containing ink. ${ }^{5}$ Within this stain, three lines are

4 Translated, the inscription reads: "Jobannes Neruet, Philhellene [i.e., 'Friend of Greeks'], in the year after the salvation of mankind, 1-600-75 [i.e., 1675]." The authors are indebted to Jamie Masters of King's College London for his translation assistance.

5 Azurite $\left[2 \mathrm{CuCO}_{3} \cdot \mathrm{Cu}(\mathrm{OH})_{2}\right]$ was a common blue pigment in the Middle Ages, and its tendency to transform into the closely related green mineral malachite $\left[\mathrm{CuCO}_{3} \cdot \mathrm{Cu}(\mathrm{OH})_{2}\right]$ has been well documented: "According to Selim Augusti . . . there is hardly a medieval Italian church where azurite in mural paintings does not show evidence of being transformed to malachite" (see Rutherford J. Gettens and Elisabeth West Fitzhugh, "Azurite and Blue Verditer," Studies in Conservation 11 (1966): 54-61, at 57. A similar chemical transformation may have occurred in our fragment's stain. Although the stain is primarily blue, significant amounts of green pigment have precipitated along the edges of these stained areas, indicating that the 
inscribed upside-down on the verso. We successfully recovered a portion of this inscription: the first line remains illegible, the second reads [ $\ldots y$ ?] $S$ - D'bumanité, and the third, perhaps a shelfmark, appears to read v.ll.c. pp. Puize.

The rubricated names Ricardus and Iob(an)nes are visible without processing, and they appear several times on both sides to indicate changes in the speaker. Additional paratextual features are also visible, though their purpose was previously unknown. For instance, we now know that the red underlining throughout was used to emphasize all direct quotations from the Bible and chapter summaries, which roughly correspond to those in the tabulae at the beginning of each liber in the 1511/12 printed edition. Red oblique marks appear throughout and were used as punctuation. Four instances of strikethrough corrections, also done in red ink, are visible on the recto. Blue and red paraph marks are scattered throughout the text, usually appearing before the names Ricardus and Iohannes or chapter summaries. Two pen-flourished initials-a six-line $I$ on the recto and a threeline $U$ on the verso-decorate the folio; the blue ink that once formed the bodies of the letters has faded significantly, but the elaborate red penwork designs surrounding them remain.

The text itself is divided into two columns of fifty lines each. The text is written in a bold cursiva libraria, while the rubricated names are written in a slightly larger textualis formata. Based on paleographic evidence, the manuscript was likely produced in southern France in the mid-fourteenth century. The production location can be surmised from the combination of French and Italian letter forms without the characteristic roundness of a true Italian hand. ${ }^{6}$ The scribe employs certain letter forms more common

pigment has oxidized; this is most visible in the small, circular stain between the third and fourth sewing support holes on the verso spine.

6 For discussion of different cursiva letter forms and their geographic affiliations, see Albert Derolez, The Palaeography of Gothic Manuscript Books: From the Twelfth to the Early Sixteenth Century (Cambridge: Cambridge University Press, 2003), 142-62. Huskin first posited that the fragment originated in southern France or possibly northern Italy in the third quarter of the fourteenth century. Ilya Dines proposes that it was most likely produced in southern France and suggests a more precise date range of 1340-60 for the script (email messages to authors, 27-28 March 2018). While the authors are reticent to claim with certainty such a 
in Italian manuscripts, such as the lack of horns on $g$; the 3 shape of $m$ in final position; the vertical descender of $p$ and its body in varying states of closure; and three distinct $r$ formations, including a majuscule $R$ that is only very rarely used in the first-letter position. However, the scribe's construction of $f$ and long-s more closely resembles that of a French batarde script: they have long, moderately rightward-slanting descenders that are consistently more slanted than the descenders of $p$ except when $s$ and $p$ are written adjacent to one another, and they consistently have straight, not curved, downward-angling top strokes. ${ }^{7}$ The date may be more precisely estimated as being after circa 1350, based on when we know the text was

narrow range, Dines's dating would make our fragment the oldest extant copy of FitzRalph's Summa by fifteen years. Michelle Brown accepts a mid-fourteenth-century timeframe; however, she believes the script to be a "bastard anglicana incorporating secretary features," a style that "is found in English territory (incl[uding] parts of [F] rance under English control), not in French territory" (email messages to authors, 9 May 2018). After careful consideration, the authors have concluded that an English origin is unlikely. The authors fail to identify any of the most distinctive anglicana letter forms-namely, a boxy two-compartment $a$, a two-compartment 8 -shaped $g$, and either a forked $r$ extending below the baseline or a two-stroke textualis-style $r$ (see Jane Roberts, Guide to Scripts Used in English Writings up to 1500 (Liverpool: Liverpool University Press, 2015), 161-64, and Malcolm B. Parkes, English Cursive Book Hands, 1250-1500 (Oxford: Clarendon, 1969), xiv-xviii). Notably, all examples of fourteenth-century English manuscripts in Thomson feature a two-compartment $a$ and an 8 -shaped $g$, and a nearly equal usage of a forked and two-stroke $r$ (see S. Harrison Thomson, Latin Bookbands of the Later Middle Ages, 1100-1500 (Cambridge: Cambridge University Press, 1969), pl. 96-103). The example of "bastard anglicana" in Brown shows the same $a, g$, and textualis-style $r$ (see Michelle P. Brown, A Guide to Western Historical Scripts from Antiquity to 1600 (Toronto: University of Toronto Press, 1990), 100-101). While Brown seems to regard the "fusion of the rounded loops" as characteristic of anglicana, Derolez regards this as a general cursiva feature (Brown, Guide to Western Historical Scripts, 100; Derolez, Palaeography of Gotbic Manuscript Books, 142ff.). Given the absence of other anglicana letter forms in our fragment, the authors would posit that our fragment's script does show similarity to Parkes's examples of secretary bookhands, but these were all produced in the fifteenth century (see Parkes, English Cursive Book Hands, pl. 11-13). It is generally accepted that secretary first arrived in England circa 1375 after making its way up through northern Italy (where it originated ca. 1350) through southern and then northern France (Roberts, Guide to Scripts, 211; Parkes, English Cursive Book Hands, xix). Because our fragment was likely made before 1370, its use of certain secretary features likely supports the initial hypothesis of an origin in southern France.

7 See Derolez, Palaeography of Gothic Manuscript Books, 155-60. 
composed, and before circa 1375, based on a comparison to two dated manuscripts written in a French "school hand" that closely resembles the script used in our fragment. ${ }^{8}$ This script shows a clear evolution from its use in a 1356 copy of Thomas Bradwardine's De Causa Dei (pl. 18) and its use in a 1378 copy of Petrus de Candia's Lectura in Sentencias (pl. 20). The overall style of our fragment's script falls squarely between that used in 1356, which employs some distinctly textualis forms, and that used in 1378, which shows a clear tendency toward currens. Our scribe primarily uses the cursiva forked $r$ that predominates in 20 rather than the textualis $r$ that predominates in plate 18; however, the later forms of $b$ and $d$ that occur regularly in plate 20 and appear only rarely (if ever) in manuscripts produced before 1378 are completely absent in our manuscript. Additionally, the similarities between the Ricardus fragment's decorated initials and those of plates 18,19 , and 21 are striking. ${ }^{9}$

\section{Manuscripts and History}

Oxford-trained theologian Richard FitzRalph (ca. 1295-1360) wrote several sermon collections, philosophical treatises, and anti-mendicant tracts. Although his theological contributions have now been largely overshadowed by those of his contemporary John Wyclif (ca. 1320-1384), FitzRalph contributed to debates about time and future contingents, as well as the relationship of predestination and free will in response to the heretical predestinarianism teachings of another of his contemporaries, Thomas Bradwardine (ca. 1300-1349). ${ }^{10}$ Written to address the temporally pertinent issue of doctrinal disputes between the Roman and Armenian churches, the Summa de Questionibus Armenorum is most notable now for FitzRalph's

8 Thomson, Latin Bookhands of the Later Middle Ages, pl. 18 (France, 1356) and 20 (France, 1378).

9 See Thomson, Latin Bookhands of the Later Middle Ages, pl. 18 (France, 1356), 19 (France, 1367), and 21 (France, 1391).

10 Michael W. Dunne, "Richard FitzRalph," Stanford Encyclopedia of Philosophy, ed. Edward N. Zalta, 3 July 2013, https://plato.stanford.edu/entries/fitzralph/ (accessed 7 July 2018). 
decision to cite Scripture as his sole source of auctoritas. The text follows a logical structure, and its two personae, Ricardus and Johannes, represent the perspectives of FitzRalph (as a spokesperson for the papacy) and of a generic pupil (as a stand-in for the Armenian prelates) whose heterodox beliefs must be brought into conformity with Roman Catholic doctrine. Books 1-10 address the doctrinal errors of which the Armenian and Eastern churches had been accused. Book 10, from which our fragment comes, addresses the sacramental powers and limitations of the priesthood; chapters 14-17 treat simony. Books 11-14 take up the debate on the beatific vision that had been contested as recently as circa 1338-44, when prelates from the Roman, Armenian, and Greek churches met in Avignon. Books 16-19 address contemporary theological debates among those of the upcoming scholastic generation and the rational supremacy of Christian Scripture over that of Muslims and Jews. ${ }^{11}$

The Summa was widely disseminated in the Middle Ages, becoming a standard text in theological centers, including Paris. Katherine Walsh, surveying the surviving witnesses, identifies thirty-seven complete or nearly complete manuscripts and eight fragments (not including this one). ${ }^{12}$ As discussed in greater detail above, the Rochester fragment was likely written in southern France before 1375. Paris and Avignon were the earliest and most prolific production centers of Summa manuscripts, with the earliest known (lost) copies having originated at the papal library in Avignon. The earliest extant text is Kraków, Biblioteka Jagiellońska, MS 1599 (DD.VI.1), which was copied in Paris in 1375, although multiple older copies are known to have existed. ${ }^{13}$ The earliest of these must have been the dedicatory copy that FitzRalph claims to have presented to Clement VI sometime after he was appointed Archbishop of Armagh in 1347 but prior to Clement VI's

11 For a more detailed analysis of the Summa's dating, structure, historical context, manuscript history, and theological content, see Walsh, Fourteenth-Century Scholar and Primate, $131,145-75$.

12 Walsh, Fourteenth-Century Scholar and Primate, 461-62. See also Carmen Cardelle de Hartmann, "R57a. Summa (Liber) de quaestionibus Armenorum / De erroribus Armenorum (quaestiones)," in Lateinische Dialoge, 1200-1400: Literaturbistorische Studie und Repertorium (Leiden: Brill, 2007), 592-95.

13 Walsh, Fourteenth-Century Scholar and Primate, 130n4. 
death in $1352 .{ }^{14}$ The papal library catalogs attest to three other early copiestwo in Clement VI's possession that must postdate the dedicatory manuscript and one made circa $1370-75$ for Gregory XI. ${ }^{15}$ It is impossible to determine with certainty whether our fragment comes from any of these lost copies, as the catalog records are nondescript. However, the combination of its presumed location of origin and date of production, as well as its known transit to Normandy, raises the tantalizing possibility that our manuscript may be the remnants of one of Clement VI's copies when his library was dispersed across France under Benedict XIII. Leaving such speculation aside, though, the Rochester fragment is nevertheless significant to the study of Richard FitzRalph's corpus because it is the first copy of any of his works to be identified in a non-European collection. ${ }^{16}$

When and by what conduit the Nervet family acquired the fragment is a matter of informed conjecture. The Jean Nervet of the inscription was junior scion to an ancient and prominent family from Evreux in Normandy. Born on 21 August 1658, the philhellene Jean displays a dedication to Greek that was no doubt the product of both youthful exuberance- he was seventeen at the time of the writing-and rare classical erudition. His forebear Jean Nervet I (1442-1525), who served as the confessor of Louis XI, Abbot

14 Walsh, Fourteenth-Century Scholar and Primate, 130-31, especially at 130, n. 3. See also Anneliese Maier, Ausgehendes Mittelalter: Gesammelte Aufä̈tze zur Geistesgeschichte des 14. Jabrbunderts, 3 vols., Storia e Letteratura Raccolta di Studi e Testi 97, 105, 138 (Rome: Edizioni di Storia e Letteratura, 1964-77), 3:1-53.

15 See Walsh, Fourteenth-Century Scholar and Primate, 130, n. 4. On the two manuscripts made for Clement VI, see Maier, Ausgehendes Mittelalter, 3:21-25, items 90 and 127. The copy of the Summa in item 90 was bound with a copy of the Regula Benedicti and other books ("alij libri"), and the entire volume was written on paper ("papiro") and bound in decorated leather ("corium leonatus"). The copy in item 127 was presumably the only text in that codex, although the entry gives only the rubricated title, "tractatus de questionibus armenorum." For more on the manuscript made for Gregory XI, see Franz Ehrle, Historia Bibliothecae Romanorum Pontificum (Rome: Typis Vaticanis, 1890), 558, item 1639. The papal cataloger provides the incipit of the second and penultimate folios, but because the Summa is in prose, there is no way to determine the number of lines per page from this information.

16 Walsh, Fourteenth-Century Scholar and Primate, 461. Cardelle de Hartmann in 2007 updates Walsh's 1981 inventory, but she still does not locate any copies of the Summa in a non-European collection ("R57a," in Lateinische Dialoge, 592-95). 


\section{Manuscript Studies, Vol. 4 [2019], Iss. 2, Art. 5}

of Juilly, and later Bishop of Megara, was intimately involved both in Parisian court life and at the epicenter of academic theology in sixteenth-century France.$^{17}$ His fortunes and prominence in the Church, and his association with the newly founded Collège Royal (1530), now the Collège de France, no doubt lay the foundations of the Nervet library, whose renown lasted until the end of the Nervet line in the late eighteenth century. ${ }^{18}$ Crucial to both the religious and classicizing cast of the Nervet library was Jean Nervet I's patronage of the celebrated young Hellenist and Hebraist Jean Chéradame, later professor of Greek at the Collège Royal (ca. 1543) and author of the Greek grammar textbook Grammatica isagogica Joannis Cheradami (1521). ${ }^{19}$ Whether or not Jean Nervet I acquired the Ricardus fragment himself, the scholarly tradition instilled by Chéradame in the Nervet family endured into the following century when Jean Nervet II, along with his four brothers, all earned acclaim as linguists and scholars highly proficient in Latin, Greek, and Hebrew. ${ }^{20}$ If we are correct in our conclusion that the three-line inscription within the large blue stain is indeed a library shelfmark, then this, along with the use of D'bumanite, would suggest that the rebound volume was held in a relatively large French library, such as that of the Nervet family. Because the text itself is so heavily abbreviated (it is not uncommon for every word in a line to be truncated), it is also likely that the fragment would have been nearly unusable by anyone but students or teachers of theology. ${ }^{21}$ As France

17 See Gallia Christiana [. . . Tomus Quartus (Paris: Typographia Regia, 1728), 787.22, and Gallia Christiana [. . .] Tomus Octavus (Paris: Typographia Regia, 1744), 1677-78.13.

18 See "Achille-Nicolas Nervet: Conseiller Receveur des Tailles, en l'Élection d'Évreux et sa Marque de Bibliothèque," Archives de la Société Française des Collectionneurs d'Ex-Libris 3, no. 10 (1896): 145-47.

19 See Jugements sur Quelques Ouvrages Nouveaux, 1744-1745, ed. Pierre-François Guyot Desfontaines (Avignon: Pierre Girou, 1745; reprint, Geneva: Slatkine Reprints, 1967), 8:168-69.

20 See s.v. "Nervet," Biographie Normande: Recueil de Notices Biographiques et Bibliographiques sur les Personnages Célèbres nés en Normandie et sur ceux qui se sont Seulement Distingués par leurs Actions ou par leurs Écrits, ed. Théodore Lebreton (Rouen: Librairie de la Bibliothèque Publique, 1861), 3:140-43.

21 Derolez, Palaeography of Gothic Manuscript Books, 153-54. 
remained a majority-Catholic country until 1675, the most logical explanation for its excision is that its codex was in disrepair and/or that its content was determined to be outdated (it was clear by the Council of Ferrara-Florence in 1439 that the East/West Schism would not be mended). ${ }^{22}$ Given the history of the Nervet family and its library, that excision likely occurred between the sixteenth and seventeenth centuries, during the period of scholastic activity of either Jean I or II.

\section{Multispectral Imaging}

MSI is a photographic technique for recovering faded, damaged, or palimpsested text from manuscripts. The current state-of-the-art in capture technology evolved from the efforts in the first decade of the twenty-first century to recover two previously unknown works by the Greek mathematician Archimedes from a tenth-century palimpsest. ${ }^{23}$ This modern capture setup, used by the Lazarus Project at the University of Rochester, consists of five key hardware elements: (1) light-emitting diodes (LEDs) for object illumination, (2) a 50-megapixel monochrome camera sensor, (3) an apochromatic lens, (4) a filter wheel to separate fluorescence from reflectance, and (5) a multispectral transmissive light source to illuminate through the folio. A series of up to forty-four images per side is captured in three distinct modalities: reflectance, fluorescence, and transmissive. Once the

22 Nicholas Pickwoad, "The Use of Fragments of Medieval Manuscripts in the Construction and Covering of Bindings on Printed Books," in Interpreting and Collecting Fragments of Medieval Books: Proceedings of the Seminar in the History of the Book to 1500 (Oxford, 1998), ed. Linda L. Brownrigg and Margaret M. Smith (Los Altos Hills, CA: Anderson-Lovelace, 1998), $1-20$ at 2.

23 Much has been written on the Archimedes Palimpsest and the recovery via multispectral imaging of its undertext, but see in particular Reviel Netz and William Noel, The Archimedes Codex: How a Medieval Prayer Book is Revealing the True Genius of Antiquity's Greatest Scientist (Cambridge, MA: Da Capo Press, 2007). See also Roger L. Easton, Jr., and William Noel, "Infinite Possibilities: Ten Years of Study of the Archimedes Palimpsest," Proceedings of the American Philosophical Society 154, no. 1 (2010): 50-76. 
capture process is completed, the images are processed using specialized statistical algorithms and exported to scholars for study. Capturing multispectral images of cultural heritage objects is a non-destructive, noninvasive process. ${ }^{24}$

The target object is placed on a stand beneath the sensor. This sensor is equipped with an apochromatic lens that, unlike those found in traditional cameras, can capture the ultraviolet (UV) and infrared (IR) regions of the spectrum. A ColorChecker Color Rendition Chart and a Spectralon target are placed beside the object in the frame to allow for image calibration and color correction. ${ }^{25} \mathrm{~A}$ filter wheel is affixed to the camera below the lens. The main LED banks are placed at a 45-degree angle to the object, behind diffuser screens. These LEDs emit sixteen discrete wavelengths of light. Beginning in the UV at 365 nanometers (nm), the LEDs cycle through the visible spectrum and into the IR (up to $940 \mathrm{~nm}$ ). The camera captures a monochrome image of the object under each wavelength and stores these images as separate files on the computer.

This stage captures reflectance images, in which light bounces off of the object and into the camera lens. Next, fluorescence images are captured. Parchment exhibits mildly fluorescent properties; that is, it absorbs shorterwavelength light and emits it at longer wavelengths. The six filters in the filter wheel (UV block [Schott GG400], UV pass [Hoya U360], orange [O22], red [R25], green [G58], and blue [B47]) selectively block some

24 The total combined illumination to which a document is exposed during the course of a MSI capture session amounts to "less than the normal room light exposure required to prepare the object for capture" (see Greg Bearman, Ken Boydston, and Bill Christens-Barry, "Measuring the Illumination Exposure of LED Illuminants in a Multispectral Imaging System,” MegaVision, Inc., http://www.mega-vision.com/news/pdfs/LED_exposure_of_EV_ System_at_IAA.pdf (accessed 2 July 2018), 1-6 at 6). In this respect (and in all others), modern systems are a vast improvement over their forebears, which used heat-generating broadband light sources instead of the cool, discrete-band LEDs now employed.

25 Spectralon is a fluoropolymer related to Teflon that has the highest reflectance of any material between the ultraviolet, visible, and near-infrared portions of the spectrum. In simpler terms, it is the whitest substance available for fine color calibration of images. We have championed its use in cultural heritage imaging, where it is not well known. 
wavelengths while allowing others to pass through, enabling the sensor to capture the different spectral responses of the various inks, stains, and pigments on the object.

Finally, if the object to be imaged is translucent (as parchment is), a transmissive light source is employed. This light source takes the form of a slim piece of acrylic upon which a single folio of the manuscript rests. Affixed to the acrylic is an LED light bar that emits four wavelengths: cyan $(505 \mathrm{~nm})$, amber $(570 \mathrm{~nm})$, and two infrared bands (780 $\mathrm{nm}$ and $940 \mathrm{~nm}){ }_{.}^{26}$ The light shines upwards through the manuscript and is recorded by the camera. ${ }^{27}$ This is useful for palimpsests in which the undertext is so decayed that it has left only a thinning of the parchment. Such thinning may not be detectable using light shone from above, but it may be illuminated by light from below.

The key to a successful multispectral project, however, lies less with the technology of the lights and camera than with the computer processing that is performed on the images after they have been obtained. For this the Lazarus Project uses ENVI (ENvironment for Visualizing Images), developed by Harris Geospatial Solutions. The single-band images are compiled into what is called a cube: a data set that virtually "stacks" the images one on top of the other, like a sheaf of papers. Flat field calibration is performed across the cube to ensure universal white balance and color accuracy.

Next, the cube is subjected to statistical processing, chiefly (for the present manuscript) principal component analysis (PCA), blur and divide (BAD), and spectral angle mapping (SAM). PCA uses orthogonal transformation to reduce the dimensionality of a large data set (e.g., the forty-four images that make up the image cube) to a smaller data set in which the component

26 Shorter wavelengths, such as ultraviolet, do not penetrate materials and so are not used when capturing transmissive images.

27 Unbound folios like the Ricardus Dialogue can be placed flat upon the transmissive light source. Bound manuscripts necessitate the use of a cradle designed specifically to hold the codex in place at an angle so that one folio at a time can be placed on the light source and imaged. 
variables are maximally uncorrelated. ${ }^{28}$ This serves to make greater visual distinctions between points that may otherwise be indistinguishable to the human eye. BAD enhances the image by dividing it by a blurred version of itself, which has the effect of enhancing contrast and evening out background variation. Lastly, SAM is a method of assessing the similarity between two pixels: the processor selects a set of reference pixels (i.e., the text he or she wishes to enhance), and the software computes the spectral angle between that reference and every other pixel that composes the image. The result is a map, across the image, of pixels that are most similar to that reference.

Processing methods vary depending on the object's condition, state of legibility, and substrate. In the case of the Ricardus Dialogue, various parts of the same object (e.g., the main body of the text, the spine, and a stained portion near the bottom) all have discrete spectral properties and thus respond differently to imaging. This variation means that each section must be processed differently either in ENVI or in Adobe Photoshop. Photoshop is often employed as a post-processing measure to adjust brightness and contrast, change color levels, convert the image into black and white, rotate hue, and so on. These modifications are made merely to improve legibility. The final result is a plurality of images: some show the spine clearly but allow the main body of the text to remain obscured, others focus on the early modern handwriting, and so on. In the case of the Ricardus fragment, one image (fig. 2) recovers most of the Summa text, though further processing was needed to decipher words in more heavily damaged regions, such as the spine, the bookplate, and the uppermost and far-left regions where the edges had been turned in. The early modern text in the blue-stained region shows the results of iterative processing: multiple attempts at processing and reprocessing the same region in order to restore as much legibility as possible (fig. 3).

28 See Paweł Czapski, Jan Kotlarz, Katarzyna Kubiak, and Miłosz Tkaczyk, "Principal Component Analysis of Multispectral Images," Prace Instytutu Lotnictwa 234, no. 1 (2014): 143-50, and Stefano Baronti, Andrea Casini, Franco Lotti, and Simone Porcinai, "Principal Component Analysis of Visible and Near-Infrared Multispectral Images of Works of Art," Chemometrics and Intelligent Laboratory Systems 39, no. 1 (1997): 103-14. 
Huskin et al.: Multispectral Recovery of Summa de Questionibus Armenorum

Huskin, Zawacki, and Heyworth, Multispectral Recovery of a Fragment | 375

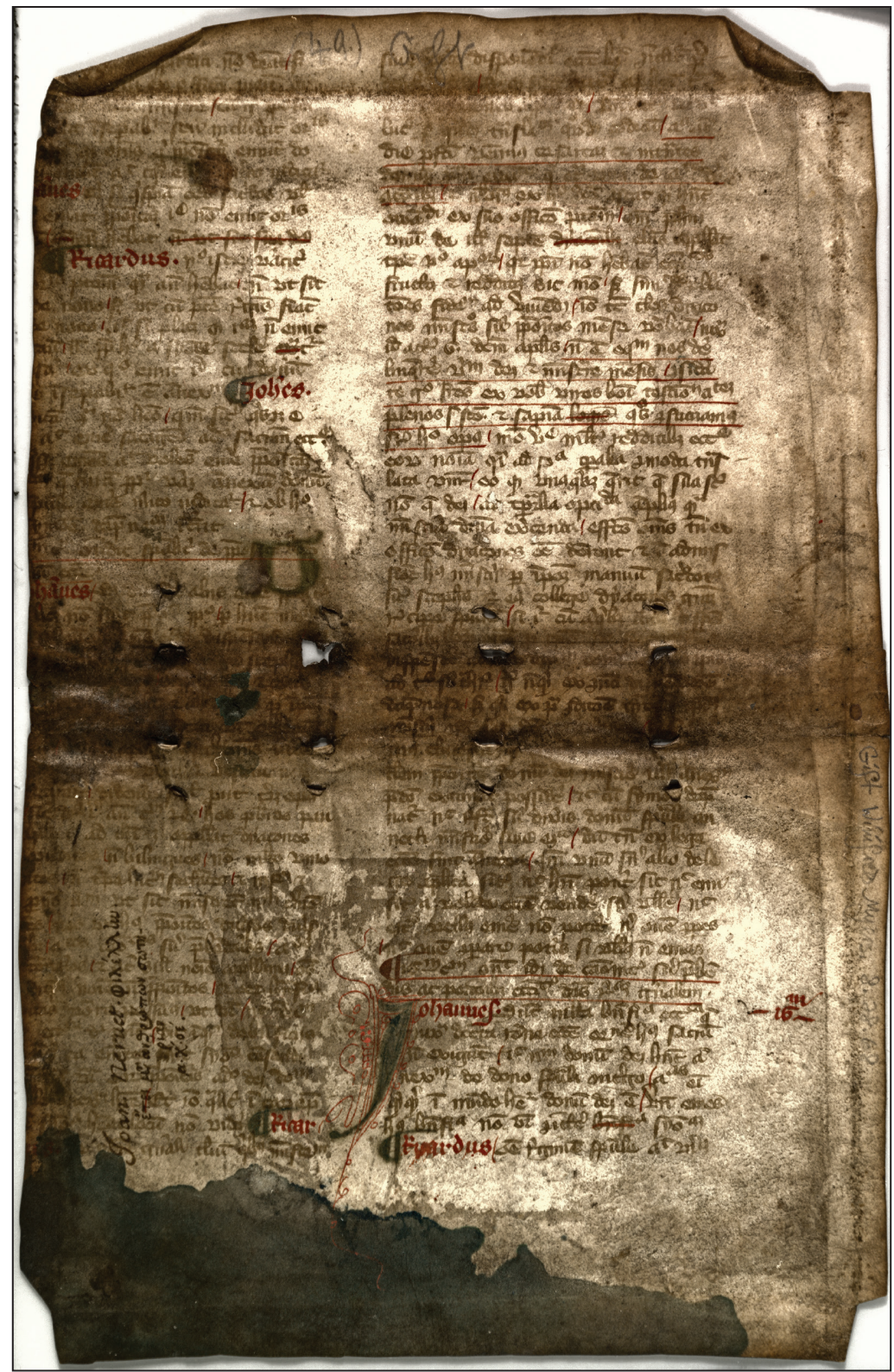

FIGURE 2. A multispectral image of the verso side after processing in ENVI. During post-processing in Photoshop, the pseudocolor image was converted to black and white and the contrast was enhanced. The resulting image was then recombined with the original RGB image. 
Manuscript Studies, Vol. 4 [2019], Iss. 2, Art. 5

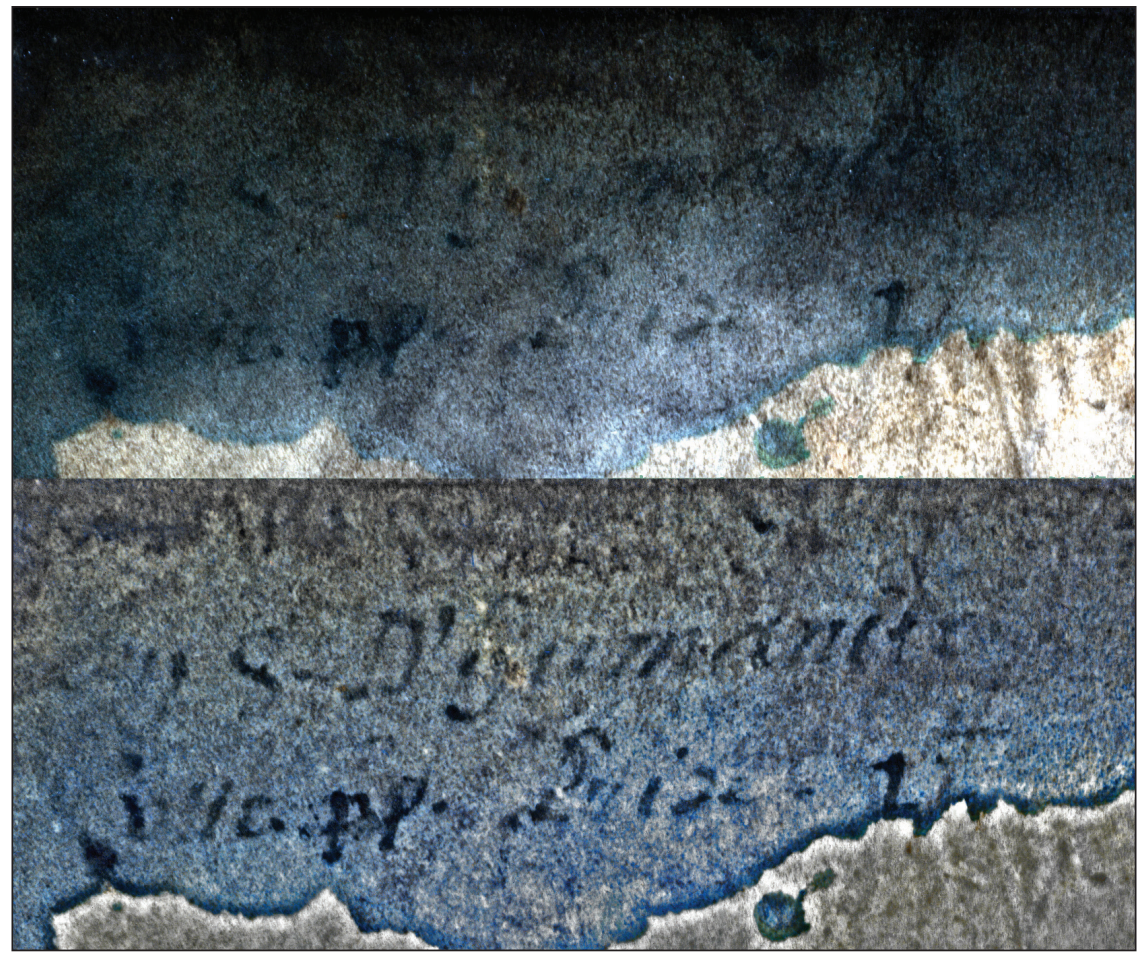

FIGURE 3. Detail of the early modern shelfmark, from the lower right corner of the recto side. Top: an unprocessed RGB image of the inscription as it appears to the naked eye. Bottom: a processed image generated in ENVI using SAM and BAD, then subjected to post-processing in Photoshop.

\section{Transcription}

The following transcription derives primarily from the Ricardus fragment, referred to in notes as MS. In places where our manuscript is illegible or nonexistent, we have supplied text in brackets from the only printed edition, referred to in notes as "1511/12." ${ }^{29}$ Where neither our manuscript nor

29 Richard FitzRalph, Summa Domini Armacani in Questionibus Armenorum: Noviter Impressa et Correcta a Johanne Sudoris cum Aliquibus Sermonibus Eiusdem de Cbristi Dominio, ed. Johannis Sudoris (Paris: venales habentur in vico diui Jacobi sub Lilio aureo, [ca. 1512]), http://hdl.handle.net/2027/ucm.5320228710. The edition was "printed by Jean Petit, a book- 


\section{Huskin et al.: Multispectral Recovery of Summa de Questionibus Armenorum}

Huskin, Zawacki, and Heyworth, Multispectral Recovery of a Fragment | 377

the print edition gives a clear reading, we have consulted the only digitally accessible manuscript variants, those in Vat. lat. 1033, 1034, and 1035. We have attempted to provide as diplomatic a transcription as possible, preserving features such as the vertical lines indicating punctuation, strikethroughs, and underlining. Abbreviations have been expanded with italics.

[1 $\left.\mathbf{r}^{\mathrm{a}}\right] \quad$ [prepositus ecclesiasticus] populi dici non debeat ${ }^{30} \mid$ sed [ille est vere prepositus] cui ex officio convenit ei [salutis] sacramenta necesaria ministrare | cum igitur prepositura [ecclesiastica habe] at inseperabiliter seu includit ordinis

5 [potestatem consequi] tur quod omnes qui preposituram emunt do[num dei] emunt aut ${ }^{31}$ tanquam e[mptor m] erito iudicatur [Joh]annes [Quid] ${ }^{32}$ si quispiam e[xistens] sacerdos vel [episcopus] emat preposituram illa $\mathrm{e}^{33}$ non emit ordinis [potestatem emit quam illam ${ }^{34}$ habebat non ut sic sua de

10 I Ricardus. ymo iste ${ }^{35}$ veracitur [emit] ordinis potestatem quam ante habebat. I non vt sit [sua] de nove ${ }^{36}$ | sed ut cum potestate regimine ${ }^{37}$ fiant

seller to the University of Paris, under a license issued by Louis XII on 12 March 1511, and the preparation of the edition was carried out by Johannis Sudoris, who also added a text of the four principal anti-mendicant sermons" (see Walsh, Fourteenth-Century Scholar and Primate, 126). Walsh dates the edition to 1511 based on the license issue, but no date is given in the text itself, and HathiTrust gives 1512. We have therefore decided to refer to it as "1511/12" here.

30 debeat. So MS. 1511/12: debet.

31 aut. So MS. 1511/12: j.

32 Quid. So 1511/12. MS may likewise read quid, but the abbreviation is partially obscured by damage.

33 illae. So MS. 1511/12: iste. MS could possibly be expanded to iste, but $i^{e}$ is given only as illae, - primae (xv) in Adriano Cappelli, Lexicon Abbreviaturarum: Dizionario di Abbreviature Latine ed Italiane (Milan: Ulrico Hoepli, 1961), 169.

34 emit quam illam. So 1511/12. MS: illegible.

35 iste. So MS. 1511/12: ille.

36 nove. So MS. 1511/12: nouo.

37 regimine. So MS. 1511/12: regiminis. 
[sua] de nove ${ }^{38}$ | aut si placem quod ${ }^{39}$ illam non emit [in hoc c] asu I non propter hoc a symonie scelere examinatur

15 [excu]satur | ex quo emit illud cui donum [spirituale] inseperabiliter est annexum II Johannes.

[Quid d]icam contra non habeo | quoniam sicut quiscumque e[met] aut emere satage $n$ s adverso ${ }^{40}$ sacramentum ecclesie [sic quicunque] emens aut volens emere ${ }^{41}$ preposituram

20 [ecclesiasti]cam que curam populi veram annexa $m^{42}$ donum [dei s]pirituale emere merito iudicatur | ] ob hoc [cum s]ymonie dampnatorum ${ }^{43}$ in currit

[I 15m] capitulum ostendit spiritualiter de prepositura [bonorum] [spirituale] ecclesie

25 [Jo]hannes $\mid$ Sed di[c d]e aliis ecclesie prepositur $[i]^{44}$ lic[et] non sint prepositi populo per hunc modum [tamen] [sunt prepositi donis] ecc[lesie] dispens[andis sicut legimus] [in actibus apostolorum capitulo] 6o de stepha[no j] [] sex suis collegis] sancto ${ }^{45}$ philipp[o] ] cetieris

30 [qui erant] a discipulis [ecclesie] ${ }^{46} \mathrm{~J}$ ab a[postoli]s per impositione [manuum] ordinati aut s[ancti]ficati vt obl[at]iones [fidelium de quibus] ap[ostolii ] discipuli] omnes v[ixerunt] [reciperent et eis in] victu j vestitu necessaria [ministrarent diui]dendo s[ingu]lis prout cuiuscumque $e^{47}$ opus 35 [erat sicut dicitur] ibi ante capitum 14. | hos presbyteros pau[lus .i.] ad thimotheum .3. appellat dyacones [similiter] p[udic]os | non bilingues | non multo vino

38 nove. So MS. 1511/12: nouo.

39 placem quod illam. So MS. 1511/12: placet dicit quia.

40 adverso. So MS. 1511/12: aliquod.

41 aut volens emere. So MS. 1511/12: aut emere volens.

42 veram annexam. So MS. 1511/12: veram babet annexam.

43 dampnatorum. So MS. 1511/12: dampnationem.

44 ecclesie preposituris. So MS. 1511/12: preposituris ecclesie.

45 MS: partially obscured, but probably $s$ followed by superscript $o$ for sancto.

46 ecclesie. So 1511/12. MS illegible.

47 cuiuscumque. So MS. 1511/12: cuius. 
[deditos] | non turpe lucrum sectantes | ] inf $r a^{48}$ ] [huius probant] primum vt sic ministro ${ }^{49}$ nullum crimem

40 [habentes] | nos v[ero] huius prepositos ${ }^{50}$ diversos diversis [nominibus] | [aliquos canoni]cos sum prebendarios | alios [portionarios] | [aut simili] ${ }^{51}$ nomine appellamus | omnes [tamen dictimus] nomine communi prepositos | ] eorum beneficia [preposituras] vocare possumus ${ }^{52}$ | vt videtur nec dubium

45 [quin ecclesiasti]ce dici possunt] | dic in quam de beneficiis [huiusmodi nunquid] ea ementes sint symoniaci censendi [quoniam non] videtur eorum preposituras adverso dei donum ${ }^{53}$ [spirituale annexum] habere | Et ideo qualiter in eorum emp[tione symonia] habeat locum non vid[eo] II Ricar-

50 [dus de nomine] generali talium quibus ministeriem

[1 $\left.\mathbf{r}^{\mathrm{b}}\right]$ sive auctoritas disponendi ecclesie bona comittitur prudentur [dicis scilicet] quod sint ${ }^{54}$ iuxta apostolicam traditio[nem dya]cones appellandi | vnde actuum 12 dicit lucas secundum $\mathrm{q}[$ uan $] \mathrm{d}$ am translationum quodam codicum $m^{55} \mid$ alia autem

55 die profecti venimus casaream j intrantes domum philippi evangeliste qui erat unus de 7tem dyaconibus|子 nibilominus ex hoc dicto constat quod habebant evangelizandi ex suo officio potestatem | quoniam philippum vnu $m$ de illis septe $m$ dyaconibus electis appellat

60 tempore vero apostolorum | quia ipsi non habebant ecclesiasticos fructus ] redditus sicut modo | sed simplices oblationes fidelium ad vivendum $\mid$ ideo tunc electos dyaco-

48 j infra. So MS. 1511/12: ibi.

49 ministro. So MS. 1511/12: ministrare.

50 buius prepositos. So MS. 1511/12: buius modi prepositos.

51 portionarios aut simili. So 1511/12. MS partially illegible.

52 possumus. So 1511/12. MS: scribe appears to have accidentally left out the $m$.

53 adverso dei donum. So MS. 1511/12: aliquid donum dei.

54 sint. So MS. 1511/12: sunt.

55 quodam codicum. So MS. 1511/12: quorumdem. 
nes $^{56}$ ministros sub prepositos mense vocabant | iuxta illud actuum 6. dictum apostolis | non est equum nos dere-

65 linquere verbum dei j ministrare mensis considerate ergo fratres ex vobis viros boni testimonii 7tem plenos spiritus sancto j sapientia toquentes quos constituamus super hoc opus $\mid$ modo vero multis redditibus ecclesie eorum nomina quasi ad sola temporalia commoda trans-

70 lata videntur | eo quod unusquisque querit que sua sunt non que dei | ad temporalia optinenda amplius quam ministeria divina ${ }^{57}$ exercenda $\mid$ effectus ${ }^{58}$ omnes tamen ex officio dyacones esse deberent $\mathrm{J}$ in admissione huius ${ }^{59}$ ministerii per impositionem manuum sacerdotis

75 sicut stephanus j eius college dyacones gratiam recipere [spirituale] | si igitur cum aliquibus [talibus] dispensationibus [bonorum ec clerie pro tempore ne fiant dyacones] dispensetur a[d ipsorum] dampnum don[um dei ad ips] is ad tempus s[ubs]trahitur | ergo nunquid ${ }^{60}$ ex con[sequenti dispensatione]

80 dampnosa / sed [quid] ex prima conditione [gratiosa ipsius] ministerii [ipsi conueniat debemus attendere quod si feceri-] $\mathrm{m} u s$ el[ucescit quod omne tale ministerium siue] talem praeposituram donum dei ministerio illi annexum precio extimat possidere $\mid \mathrm{jc}^{61}$ cum symone damp85 natur $r^{62}$ nec refert sive $e^{63}$ dixeris donum spirituale annecti ministerio siue econtra $\mid$ dum tamen ex lege ecclesie sint annexa | quoniam vnum sine alio de le-

56 ideo tunc electos dyacones. So MS. 1511/12: ergo tales dyaconos.

57 ministeria divina. So MS. 1511/12: diuina ministeria.

58 effectus. So MS. 1511/12: affectus.

59 buius. So MS. 1511/12: buiusmodi.

60 nunquid. So MS. 1511/12: nunquam.

61 jc. So MS. 1511/12: et sic.

62 dampnatur. So MS. 1511/12: condemnatur.

63 sive. So MS. 1511/12: si. 
Huskin et al.: Multispectral Recovery of Summa de Questionibus Armenorum

Huskin, Zawacki, and Heyworth, Multispectral Recovery of a Fragment | 381

ge apostolica sicut nec haberi poterit sic nec emi

sicut a volente ouem vendere sine vellere | nec

90 econtra vellus emere non poterit nisi ouem compares ${ }^{64}$

nec ouem comparet poteris si vellus non emas.

I 16m capitulum ostendit idem de canonicis siue preben-

dis ac portionibus ecclesiasticis dans regulam generalem.

Johannes. Sunt multa beneficia ecclesiastica que $\quad-16 \mathrm{~m}-$

95 iuxta decreta restitutione ecclesie ordinem huius ${ }^{65}$ sacrum non exigunt $\mid$ jc nullum donum dei habent annexum de dono spirituali intelligo | alias enim quicquid in mundo habetur donum dei est $\mid$ vnde emens huius ${ }^{66}$ beneficia non videtur committere beneficia symoniam

100 I Ricardus | omne regimen spirituale aut verius

$\left[1 \mathbf{v}^{\mathrm{a}}\right]$ omnis auctoritate regiminis spiritual is $\mid$ jc auctoritas emen $\mathrm{di}^{67}$ donu $m$ dei est [supernaturale] intelligo | quoniam ex pur[is] naturalibus haberi non potest unde aperit ${ }^{68}$ ad Roma 120 habentes autem donationes secundum gratiam quae data est nobis

105 differentes sive prophetiam secundum rationem fidei sive ministerium in ministrando sive qui docet in doctrina qui exortatur in exortando qui tribuit in simplicitate qui preest in sollicitudine j cetera | vbi presidentiam ${ }^{69}$ donationem secundum gratiam vobis ${ }^{70}$ datam afforat ${ }^{71} \mid \mathrm{jc}^{72}$ potestatem

110 exortandi intelligo auctoritatem predicandi $\mid$ de quae $e^{73}$ eciam dicit ad Roma 40 | quomodo audient sine

64 compares. So MS. 1511/12: comparet.

65 ordinem buius. So MS. 1511/12: buiusmodi ordinem.

66 buius. So MS. 1511/12: buiusmodi.

67 jc auctoritas emendi. 1511/12 omits.

68 aperit. So MS. 1511/12: apostolus.

69 presidentiam. So MS. 1511/12: presidentia.

70 vobis. So MS. 1511/12: nobis.

71 afforat. So MS. 1511/12: affirmat.

72 jc. So MS. 1511/12: et sic.

73 quae. So MS. 1511/12: qua. 
predicante aut quomodo predicabunt nisi mittantur volens ostendere quod auctoritas predicandi est data de super a deo supra cursum naturae ${ }^{74} \mid$ nulla autem videntur

115 mibi beneficia ecclesiastica | quin habebant ${ }^{75}$ regimen ${ }^{76}$ spirituale J per communis donum dei annexum intelligo parcia$1 \mathrm{l}^{77} \mathrm{a} u \mathrm{t}$ integrum | quoniam omne collegium ecclesiasticum non dubium habet regimen spirituale saltem ministeriorum sui collegii siue sue ecclesie $\mid \jmath c^{78}$ singuli

120 canonicorum siue portionariorum | aut quomodocumque eos vocare volueris habent presidentiam spiritualem parciale $m$ autem integram que donu $m$ dei est $\mid$ ymo si recte consideres ipsa beneficentia ecclesiastica ${ }^{79}$ sua sunt regimina sive potestates regendi temporalia commoda habentes an-

125 nexa eis ex sola ordinatione ecclesie | nec sunt i[lla] temporalia aut ius ea p[erci]piendi d[icenda] bene [fictum] ecclesiasti [cum est dicendu]m que [est intentio nobilior]

portiones de[beant habere annexam] potestatem [euuan-] gel[isan]di $\mid$ j per consequens donum dei $\mid \mathrm{jc}^{80}$ ex [duplici] capite $^{81}$ talibus beneficiis sicut dona dei annexa

74 naturae. So MS. 1511/12: natura.

75 babebant. So MS. 1511/12: babeant.

76 regimen. 1511/12: regimem, perhaps in error for regimen. We emend to regimen for contextual sense and because it is the word used in all three Vatican MSS. It should be noted, however, that while our MS's abbreviation $\left(r g^{m}\right)$ should be expanded to regnum (xiv) (see Cappelli, Lexicon Abbreviaturarum, 324), our scribe variously abbreviates forms of regimen (cf. lines 100, 101, 115, 123).

77 parciale. So MS. 1511/12: particiale.

78 jc. So MS. 1511/12: et sic.

79 beneficentia ecclesiastica. So MS. 1511/12: ecclesiastica beneficia.

80 jc. So MS. 1511/12: et sic.

81 ex [duplici] capite. 1511/12: ex duplici causa. 
Huskin et al.: Multispectral Recovery of Summa de Questionibus Armenorum

Huskin, Zawacki, and Heyworth, Multispectral Recovery of a Fragment | 383

135 si quam fuerunt ${ }^{82}$ beneficia appellata | que nullam cura $m$ regis ${ }^{83}$ habent annexam nec ordine $m^{84}$ nec dispensationis spirituale ministerium | nec auctoritatem euangelizandi | sed sunt tamquam stipendia ministrantibus in ecclesia deputata pro vite neccesarie ${ }^{85}$ improprie

140 ecclesiastica appellantur | quoniam ecclesiasticica proprio nomine sola spiritualia appellamus | vnde in mercatore ${ }^{86}$ talium si qua sint non videre ${ }^{87}$ symoniam committi ${ }^{88} \mid$ breuiter tamen college quod sicut vendens quoduis donum dei gratuitum aut eius effectum seu fructum ba-

145 laamiam siue gieziam incurrit iuxta precedentem articulum | quia contra illud [agit] gratis accepisistis [gra-] tis date $]$ contra causae ${ }^{89}$ huius dicti quas ibi expressi | sic quiscumque ${ }^{90}$ emens huius donum de ${ }^{91}$ spirituale seu eius proprium effectum siue fructum ${ }^{92}$ symoniam committit | cuius

150 factum ideo est graue peccatum quia in auctorem im-

[1 $\left.\mathbf{v}^{\mathrm{b}}\right]$ pingit / volens eum per se [aut per suum spirituale] ministerium de suis donis gratui[s mercari] II Item sicut ibi dixi de ve[ndente sic dico] de emente quod laborat ali[ena in debite]

155 possidere $\mid \mathrm{jc}^{93}$ fur aut latro siue [raptor meri-] to iudic[atur] II Item namque donum dei [gratuitum] quantum est in ipso subuertit laborans ip[sum venale]

82 quam fuerunt. So MS. 1511/12: qua vero fuerint.

83 curam regis. So MS. 1511/12: omnino curam regiminis.

84 ordinem. So MS. 1511/12: ordinationem.

85 neccesarie. So MS. 1511/12: necessitatibus.

86 mercatore. So MS. 1511/12: mercatione.

87 videre. So MS. 1511/12: video.

88 committi. So MS. 1511/12: posse committi.

89 J contra causae. So MS. 1511/12: J conseqenter contra causas.

90 quiscumque. So MS. 1511/12: quicunque.

91 buius donum dei. So MS. 1511/12: buiusmodi dei donum.

92 fructum. So MS. 1511/12: factum.

93 jc. So MS. 1511/12: et sic. 
efficere precio indecenti ] propter hoc [ad balaa-] miam seu peccatum balaamie ve[ndentem impel-]

160 lit | aut saltem nulla necessitatem vrg[ente eius peccato] consentit | vnde merito sibi dici[t] potest [in felle] amaritudinis joblatione peccati vide[o te esse quod] symoni dixit $t^{94}$ petrus | vbicumque ergo in a[liquo inue-] neris hec premissa in recipiendo [a deo donum]

165 dei siue proprium eius effectum eum symo[niacum damnabilem] fideliter affirmes | vides igitur ${ }^{95}$ quod sit s[ymonia] voluntas sola seu voluntas cum oblatione [precii e-] mendi donu $m$ dei gratuitum a $u$ t e[ius effectum] | cur vero sit tam detestabile hoc p[eccatum non]

170 minus ex hiis nunc dictis appar[et] I $17 \mathrm{~m}$ capitulum ostendit symoniam committi [in dando] temporalia sicut in dando pe[cuniam.]

Ut non autem sci[as] quod [variis modis hoc] detestabile peccatum committ[atur dic si symon aliu-]

$175 \mathrm{~d}$ [pre]cium [quam] pecuniam d[are voluisset] $\mathrm{a} u \mathrm{t} \mathrm{a}[$ postolis obt] uliss[et] pro tali p[otestate habenda]

terreno seu [corpora]li [cupit spiritualem emere] potestatem | aut eius eff[ectum] sicut [peccatum vendentis]

185 effectum gratie spiritualis sicut g[iezi] f[ecit puer] helysei | sicut [legitur 4o Regum 5e capitulo quod a Naaman syro recepit pecunia] ${ }^{96}$ ] vestes equale esse [siue vendat]

94 dixit. So MS. 1511/12: dicit.

95 igitur. So MS. 1511/12: ergo.

96 The bracketed text has been supplied from MS Vat. lat. 1033, fol. 79v, which reads: legitur iiij. regum .5. capitulo quod a Naaman syro recepit pecunia. Only this MS expands the 
pro pecunia siue [pro] vestibus | quoniam [ille ponuntur]

a prophetam pro maleficio suo lep[ra percussus]

190 eque videtur suisse punitus pro vest[ibus receptis]

sicut pro recepta pecunia sicut s[ententia prophete]

in eum lata pretendit sub hiis [verbis. Nunc ergo]

accepepisti vestes ${ }^{97} \mathrm{vt}$ emeres [oliueta et]

vineta j oues j boues ] s[eruos ] an-]

195 cillas sed [j] lepra [naaman] ad h[aberit tibi j]

semini tuo in sempiternum | vnde mibi v[idetur pariter]

esse de emente ${ }^{98}$ sicut de habente vo[lutatem emendi]

pro alio apprehencia sunt sicut ${ }^{99}$ pro pecunia. I [Ricar-]

dus mibi videtur quod prouide j veraci[ter respondisti.]

$200 \mathbb{I} 18 \mathrm{~m}$ capitulum ostendit symoniam committi in [procurando]

\section{Conclusion}

As the transcription above reveals, we recovered nearly all of the text that was not removed when the folio was trimmed to fit the new volume and holes were made to incorporate its sewing supports. The resulting text, while still fragmentary, was thus able to be identified for the first time as part of Richard FitzRalph's Summa de Questionibus Armenorum, 10.14-17. Unfortunately, ten full lines of medieval text in the verso spine region, as well as some of the early modern handwriting, defied all of our processing efforts. Nevertheless, we learned a good deal about the fragment's provenance,

abbreviations fully enough to give a clear reading of the text. Our MS reads: legitur 40 Re $[\ldots]$ si. re. pe. 1511/12 reads: legitur.4.re 5.ca. quod a na. pec. Cf. also MS Vat. lat. 1034, fol. 45r: sicut legitur 4. regum.c.5. quod a.naaman si re. pc., and MS Vat. lat. 1035, fol. 110v: sicut legitur 4. R(egum) 5. co quod ana s. re. pe.

97 accepepisti vestes. So MS. 1511/12: accepisti argentum $]$ accepisti vestes.

98 de emente. So MS. 1511/12: de vendente j emente.

99 alio apprehencia s? sicut. So MS. 1511/12: alio preciabili siue. Both our MS and 1511/12 contain seemingly anomalous readings when compared with the Vatican manuscripts. MS Vat. lat. 1033, fol. 79v: alio preciabili sicut. MS Vat. lat. 1034, fol. 45r: alio pretia(bi)li sicut. MS Vat. lat. 1035 , fol. $110 \mathrm{v}$ : alio preciali sicut. 
including (1) that the manuscript from which our fragment comes was likely produced in southern France, perhaps in Avignon, or possibly in northern Italy, and (2) that sometime between its creation and 1675, this folio was excised, reused, and owned by Jean Nervet, a member of a prominent family from Évreux, Normandy. Our work shows the enormous promise of MSI technology to recover damaged cultural heritage artifacts such as the Ricardus Dialogue - as well as some of its limitations.

This recovery work will benefit the scholarly and university communities. Should anyone choose to produce a critical edition of the Summa, this fragment will provide yet another version against which they can compare their base manuscript. It may also be useful to scholars studying the transmission history of the Summa, as there appear to be two main manuscript traditions-one in a long-line format, another in a two-column formatand very little has apparently been done to determine the chronological or geographical significance of either. ${ }^{100}$ More significantly, however, our discovery will benefit the University of Rochester. The Department of Rare Books, Special Collections, and Preservation can expand the finding aid to include the text identification, provenance information from before 1675, our transcription, and the processed images so that others can read the text for themselves. This will allow students and researchers to work with the physical manuscript fragment itself as well as its digitally restored facsimile. Additionally, identifying the text has the pragmatic benefit of increasing the manuscript's monetary value. It is imperative that scholars and librarians realize that damaged manuscripts, such as the Ricardus Dialogue, are not necessarily lost causes: MSI processing can recover their contents and open the door to new discoveries. The increasing awareness and availability

100 Among manuscripts whose catalog entries provide sufficient physical descriptions or digitized images, those in the one-column tradition include Paris, Bibliothèque Mazarine, MS 896 (s. XVin), and Vatican City, Biblioteca Apostolica Vaticana, MS Vat. lat. 1033 (1393); and those in the two-column tradition include Paris, Bibliothèque Mazarine, MS 895 (s. XIV ${ }^{\mathrm{ex}}$ ) and Vatican City, Biblioteca Apostolica Vaticana, MSS Vat. lat. 1034 (1380) and 1035 (ca. 1376-1400). For more information on the Vatican Library manuscripts, see Codices Vaticani Latini, ed. Auguste Pelzer, vol. 2.1, Codices 679-1134 (Rome: Typis Polyglottis Vaticanis, 1902), 541-44; the manuscripts may also be viewed in full at https://digi.vatlib.it/mss/Vat.lat. 
of MSI technology—whether done with equipment as sophisticated as that of the Lazarus Project or as simple as a handheld ultraviolet light-means that more and more fragments will be identified.

Research on these previously unknown texts would be aided by the existence of a searchable and extensible digital database of manuscript fragments, such as Fragmentarium, "an international digital research lab for medieval manuscript fragments that enables libraries, collectors, researchers and students to publish medieval manuscript fragments, allowing them to catalogue, describe, transcribe, assemble and re-use them online." ${ }^{101}$ It is unclear whether Fragmentarium will accept images of manuscripts whose text has been identified only through multispectral imaging. Yet because fragments, by their very nature, are either abridged or damaged or both, discounting those made legible by MSI and similar means would limit significantly the number of fragments that could be included in the database, especially those from smaller institutions not included among the sixteen European and American institutions whose collections currently supply the majority of fragments included in the database. ${ }^{102}$ Indeed, smaller institutions are more likely to have fragmentary materials, particularly damaged ones, because these are typically easier and cheaper to acquire. We would propose, therefore, the creation of a supplement dedicated to fragments with impaired legibility. Here, libraries could submit images with corresponding metadata - bibliographic context, provenance, and so on-that, at the very least, identify the existence of a fragment. For its part, the Lazarus Project would be glad to image multispectrally images held by other institutions and resubmit processed images of the originals that scholars could then work to identify.

101 See Christoph Flüeler and William O. Duba, Fragmentarium: Digital Research Laboratory for Medieval Manuscript Fragments, http://fragmentarium.ms (accessed 10 July 2018).

102 Fragments from smaller institutions seem to be included in the database only if they were purchased from biblioclast Otto F. Ege as part of his "Fifty Original Leaves of Medieval Manuscripts." 
Manuscript Studies, Vol. 4 [2019], Iss. 2, Art. 5

388 Journal for Manuscript Studies

\section{Acknowledgments}

The authors extend their warmest thanks to Helen Davies of the Lazarus Project at the University of Rochester, Roger L. Easton, Jr., at the Rochester Institute of Technology, Keith Knox at the Early Manuscripts Electronic Library, and Ken Boydston at MegaVision, Inc., for their assistance in MSI capture and processing. The authors would also like to thank the University of Rochester's Department of Rare Books, Special Collections, and Preservation, particularly Anna Siebach-Larsen, Melinda Wallington, and Jessica Lacher-Feldman. We are also indebted to the work of Marjorie Harrington, who helped to produce the transcription of the manuscript. 


\section{List Of MANUSCRIPTS Cited}

Aberdeen, University of Aberdeen

MS 24: 209 n. 38, 220 n. 62, 221 n. 64, 221, 221 n. 65

Ann Arbor, University of Michigan, Special Collections Library

MS Leaf 38: 320

Baltimore, Walters Art Museum

MS W. 8: 251

MS W. 105: 187-8, 187-8 n. 1, 188 n. 2, 189 fig. 1, 190-2, 191 n. 6, 191 n. 7, 191 n. 8,192 n. 11,193 fig. 2, 194 fig. 3, 195 fig. 4, 196, 199, 201, 203, 205, 208-11, 213, 216-20, 219 fig. 12, 222-30, 222-3

n. 70, 223 fig. 13,226 fig. 14

Berlin, Staatsbibliothek

MS Or. fol. 1211: 249 n. 33

Bern, Burgerbibliothek

MS lat. 611: 335, 337-8, 343-46, $344 \mathrm{n}$. 21, 344 n. 22, 345 n. 23, 345 n. 24, 347 fig. 1, 348-52, 352 n. 28, 357-60, 357 n. 36,357 n. 37

Cairo, Karaite Synagogue

Gottheil 14: 245-6, 246 fig. 7, 249 n. 30, 264

Gottheil 17: 237, 237 n. 12

Gottheil 34: 231 n. 2, 248-9, 248 n. 27, 248 n. $28,257-8$ n. 56,260 n. 64,264

Cambridge, Cambridge University Library MS Gg. 1.1: 390-1, 390-1 n. 2, 391 n. 3, 391-2 n. 4, 392 fig. 1, 397 n. 9

MS Ii. 1.33: 340 n. 15
Cambridge, Trinity College

MS F. 12.70: 267

MS F. 12.71: 267

Chantilly, Musée Condé

MS 9: 298-9 n. 76

Cleveland, Cleveland Museum of Art, The Jeanne Miles Blackburn Collection 2011.51 fol. $390: 303,328,331$ n. 96

Columbus, The Ohio State University

Libraries, Rare Books \& Manuscripts

Library

Spec.Rare.MS.MR.Frag.74: 271-286, 271 n. 4,273 n. 7, 273 n. 8, 274 n. 10, 274 n. 11, 275 n. 12, 276 n. 13, 275 n. 14, 276 n. 16, 276 n. $18,276-7$ n. 19,277 n. 20,277 n. 21,277 n. $22,277-8$ n. 23,278 n. 24 , 279 n. 25,279 n. 26,280 n. 27,280 n. 28 , 280 n. 29,281 n. 30,281 n. 31,281 n. 32 , 286 n. 43, 286 n. 44,286 n. 45, 287 fig. 1 , 288-309, 289 fig. 2, 290 fig. 3, 290 n. 50, 290 n. 51,290 n. 52,291 n. 53, 292 n. 55, 292 n. 58, 293 fig. 4,296 n. 66, 296 n. 69, 297 n. 70, 297 n. 71, 298 n. 74, 299 n. 77, 299 n. 78, 299 n. 80,300 fig. 5, 301 fig. 6, 303 fig. 7, 304 n. 84, 306 fig. 8, 310-31, 310 n. 89,311 n. 90,331 n. 92

Copenhagen, Kongelige Bibliotek Cod. Heb. II: 236, 236 n. 9, 266

Cod. Heb. III: 268

Cod. Heb. IV: 268

Dublin, Trinity College Library

MS 16: 239 n. 14 
Manuscript Studies, Vol. 4 [2019], Iss. 2, Art. 5

\section{4 | Journal For Manuscript Studies}

MS 94 (F.5.21): 191-2, 192 n. 9

MS M 2.5: 268

Frankfurt-am-Main, Stadtbibliothek olim Ausst. 4: 236, 236 n. 9

Genoa, Biblioteca Universitaria MS D.IX.31: 268

Ghent, Universiteitsbibliotheek Gent MS 92: 334 n.1

Hamburg, Staats- und Universitätsbibliothek

Cod. Hebr. 45: 242 n. 19

Haverford, Haverford College

Rendel Harris 1: 242-3, 242 n. 19, 262, 262 n. 66,265

Iowa City, University of Iowa Special

Collections

xMMs.Br2: 410-1, 411 fig. 6

xMMs.Ps3: 409-11, 411 fig. 6

xMMs.Se1: 410-1, 411 fig. 6

Istanbul, Karaite Synagogue

Istanbul Pentateuch: 237, 237 n. 12

Jerusalem, National Library of Israel MS Heb 4º790: 233-4, 234 n. 6, 238 fig. 4, 242, 242 n. 19, 265

MS Heb 4¹112: 265

MS Heb 45147: 237, 237 n. 12

MS Heb 86527: 236 n. 7

Kraków, Biblioteka Jagiellońska MS 1599 (DD.VI.1): 368

Kremsmünster, Stiftsbibliothek

Kremsmünster

CC 243: 205, 205 n. 30, 206 fig. 7, 208

Leiden, Universiteitsbibliotheek BPL 114: 344 n. 22

Letchworth, Sassoon Collection olim MS 368: 237, 237 n. 12, 267 olim MS 508: 267
Lisbon, Biblioteca Nacional de Portugal MS I1.72: 239 n. 14

London, British Library

Cotton Roll XIV.12: 210 n. 40

MS Additional 28162: 208 n. 31

MS Additional 43120: 191-2, 192 n. 9

MS Additional 54180: 208 n. 31

MS Arundel 83 II: 197 n. 14, 203, 203 n.

27, 204 fig. 6, 220 n. 61

MS Cotton Caligula A XIV: 251, 253,

253 n. 42

MS Cotton Faustina B VII: 427

MS Harley 2253: 221, 221 n. 65

MS Harley 4751: 220 n. 63

MS Harley 5698: 268

MS Harley 5699: 268

MS Harley 5774: 267

MS Harley 5775: 267

MS Kings 1: 236-7, 236 n. 9, 241-2, 267

MS Or. 2201: 266

MS Or. 2626: 241 fig. 6, 268

MS Or. 2627: 241 fig. 6, 268

MS Or. 2628: 241 fig. 6, 268

MS Royal 2 B VII: 220 n. 63

MS Royal 10 E VII: 192 n. 9

MS Yates Thompson 13: 190 n. 5, 224 n. 73,227 n. 75

London, Lincoln's Inn

MS Hale 123: 301-2 n. 81

Madison, University of Wisconsin-Madison MS 80: 410-1, 411 fig. 6

MS 170A, no. 8: 406 fig. 2

Madrid, Real Biblioteca del Palacio Real MS II, 3231-46: 268

Marseille, Bibliothèque municipale MS 1626: 266

Modena, Biblioteca Estense Universitaria MS $\propto .0 .5 .9: 267$

MS M.8.4: 236-7, 236 n. 9, 241-3

MS T.3.8: 236, 236 n. 9 
Huskin et al.: Multispectral Recovery of Summa de Questionibus Armenorum

List of Manuscripts Cited | 435

Montpellier, Bibliothèque interuniversitaire, Section Médecine

H.196: 421-5

New Brunswick, Rutgers, The State

University of New Jersey, Special Collections and University Archives

MC 0886:13: 325

New York, The Jewish Theological Seminary of America

MS L.6: 269

MS L 44a: 265

New York, The Morgan Library \& Museum

MS G.50: 222 n. 67

MS M.163: 299 n. 80

MS M.269: 296-7, 297 n. 70, 298 n. 74

MS M.729: 200 n. 24, 201, 201 n. 25, 202

fig. 5,219 n. 60

MS M.791: 303-4, 304 n. 84

Oxford, Bodleian Library

MS Bodley 764: 220 n. 63

MS Can. Or. 42: 267

MS Can. Or. 137: 249 n. 33

MS Douce 366: 220 n. 63

MS Kennicott 2: 238-9, 238-9 n. 14, 267

MS Lyell 71: 210 n. 40

MS Oppenheim Add. 4º75: 239 n. 14, 266

MS Oppenheim Add. 4º76: 239 n. 14, 266

Oxford, Corpus Christi College

MS 70: 192 n. 9

Oxfordshire, Wormsley Library

Burckhardt-Wildt Apocalypse fol. 5: 203, 203 n. 28, 205

Paris, Bibliothèque de l'Arsenal

MS 65: 292 n. 58

Paris, Bibliothèque Mazarine

MS 895: 386 n. 100

MS 896: 386 n. 100
Paris, Bibliothèque nationale de France

MS Fr. 9220 : 197 n. 14, 213, 213 n. 48, 215 n. 50

MS Hébreu 7: 234 fig. 2, 236, 236 n. 9, 239 fig. 5, 266

MS Hébreu 20: 239 n. 14

MS Hébreu 21: 235 fig. 3, 238-9, 238-9

n. $14,262,266$

MS Hébreu 25: 265

MS Hébreu 26: 265

MS Hébreu 31: 241, 267

MS Hébreu 1314: 237, 237 n. 12

MS Hébreu 1315: 237, 237 n. 12

MS Lat. 765: 192 n. 9, 192 n. 10, 227 n. 76

MS Lat. 4629: 344 n. 22

MS Lat. 9656: 341 n. 16

MS Lat. 10756 : 335, 343-46, 344 n. 21, 344 n. 22,345 n. 23,345 n. 24, 349-50, 357-8, 357 n. 38

Nouv. acq. fr. 13521: 342 n. 19

Paris, Bibliothèque Sainte-Geneviève

MS 8: 301-2 n. 81

MS 2200: 213, 213 n. 48, 214 fig. 10, 215, 215 fig. 11

Paris, Compagnie des prêtres de Saint-Sulpice MS 1933: 237, 237 n. 12

Paris, École nationale supérieure des beaux-arts

Mn Mas. 4: 237, 237 n. 12

Parma, Biblioteca Palatina

MS Parm. 677: 268

MS Parm. 2025: 265

MS Parm. 2668: 233 fig. 1, 235-7, 236 n.

10, 261, 266

MS Parm. 2938: 239 n. 14

MS Parm. 3233: 240-1, 243, 266

Philadelphia, The Free Library of

Philadelphia

Lewis E 249 B: 211, 211 n. 44, 212 fig. 9

Lewis O 140: 240, 269 
Manuscript Studies, Vol. 4 [2019], Iss. 2, Art. 5

\section{Journal for Manuscript Studies}

Philadelphia, Science History Institute

Othmer 1: 406-9, 407 fig. 3, 408 fig. 4, 409 fig. 5

Philadelphia, University of Pennsylvania

LJS 24: 412

LJS 429: 389-90, 390 n. 1, 395-8, 396 fig 3, 397 n. 9, 398 fig. 4

Prague, Národní knihovna České republiky

XIV A 13: 251, 251 n. 41

Rochester, University of Rochester

D.460 1003-003: 361-71, 361 n. 1, 363

fig. 1, 364 n. 4, 364-5 n. 5, 365-6 n. 6, 373 n. 27, 374, 375 fig. 2, 376-388, 376

fig. 3, 377 n. 30,377 n. 31, 377 n. 32, 377

n. 33,377 n. 34,377 n. 35,377 n. 36,377

n. 37,378 n. 38,378 n. 39,378 n. 40,378

n. 41,378 n. 42,378 n. 43,378 n. 44,378

n. 45,378 n. 46,378 n. 47,379 n. 48,379

n. 49,379 n. 50,379 n. 51,379 n. 52,379

n. 53,379 n. 54,379 n. 55,380 n. 56, 380

n. 57,380 n. 58,380 n. 59,380 n. 60,380

n. 61,380 n. 62,380 n. 63,381 n. 64,381

n. 65,381 n. 66,381 n. 67,381 n. 68,381

n. 69,381 n. 70,381 n. 71,381 n. 72,381

n. 73,382 n. 74,382 n. 75,382 n. 76, 382

n. 77,382 n. 78,382 n. 79,382 n. 80,382

n. 81,383 n. 82,383 n. 83,383 n. 84,383

n. 85,383 n. 86,383 n. 87,383 n. 88,383

n. 89,383 n. 90,383 n. 91,383 n. 92,383

n. 93,384 n. 94,384 n. 95 , 384-5 n. 96 , 385 n. 97,385 n. 98,385 n. 99

Rome, Biblioteca della Comunità Israelitica

MS 3: 237, 237 n. 12, 267
Saint Petersburg, National Library of

Russia

Evr. I B 19a: 248-9, 248 n. 27, 264

Evr. II B 17: 264

Evr. II B 116: 244

Evr. II B 168: 248-9, 248 n. 27, 249 n. 31, 264

Evr. II B 269: 264

Evr. II B 1548: 245, 245 n. 25, 247, 247

fig. $8,247-8$ n. 26,264

Evr. II C 144: 248-9, 248 n. 27, 249 n. 31, 264

Stockholm, Nationalmuseum

MS B. 1726: 187, 187-8 n. 1, 190-2, 191

n. 7,191 n. $8,227-8$

MS B. 1727: 187, 187-8 n. 1, 190-2, 191

n. 7,191 n. $8,227-8$

Vatican City, Biblioteca Apostolica

Vaticana

MS Reg. Gr. 1: 250-1, 251 n. 37, 251 n. 39, 251 n. 40, 252 fig. 9, 253, 253 n. 43

MS Ross. 601: 241-2, 242 n. 19, 265

MS Vat. lat. 1033: 362 n. 3, 377, 382 n.

76, 384-5 n. 96,385 n. 99,386 n. 100

MS Vat. lat. 1034: 362 n. 3, 377, 382 n.

76, 384-5 n. 96,385 n. 99, 386 n. 100

MS Vat. lat. 1035: 362 n. 3, 377, 382 n.

76, 384-5 n. 96,385 n. 99,386 n. 100

MS Vat. lat. 1046: 362 n. 3

Vienna, Österreichische Nationalbibliothek Cod. Heb. 16: 249

Zurich, Braginsky Collection MS 243: 238-9, 238-9 n. 14, 243, 268 